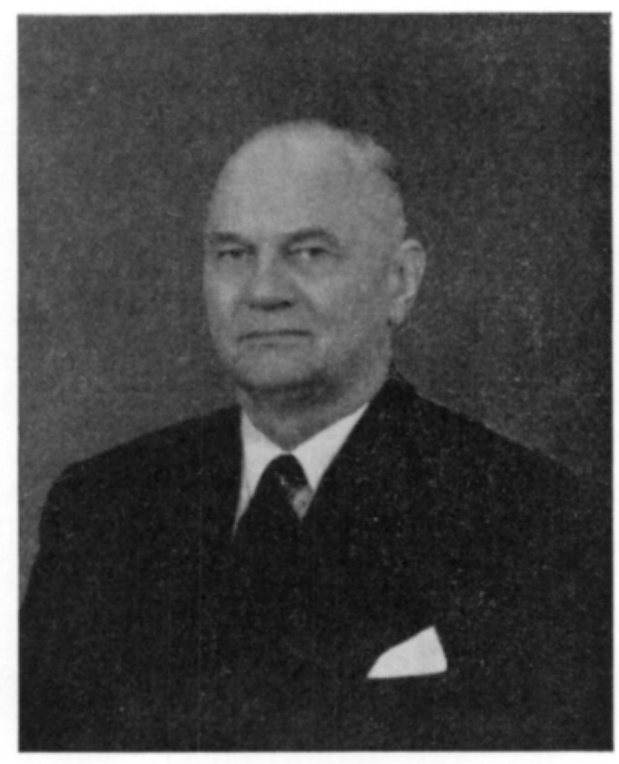

\title{
K. T. JUTILA ${ }^{1}$
}

\section{* 27. $1.1881-\dagger$ 21. 6.1966}

Professori Jutila oli suomalaiseksi ja varsinkin hämäläiseksi harvinaisen eloisa henkilö. Pirkkalasta kotoisin olevana hänessä ehkä oli muinaisten mahtavien pirkkalaispäällikköjen verta. Kun poikkeukselliseen vireyteen ja laajalle suuntautuneeseen mielenkiintoon liittyi huomattava lahjakkuus, oli tuloksena monipuolinen, useita eri elämänaloja sivuava elämänura.

Se alkoi maataloudellisena virkamiehenä metsähallituksessa ja maataloushallituksessa sekä opettajana Helsingin yliopistossa ja teknillisessä korkeakoulussa 1920-luvulla, jatkui agraaripolitiikan professorina yliopistossa 1928 -38 ja päätyi Suomen Pankin johtokunnan jäsenyyteen 1938-58.

Tähän elämänuran päälinjaan liittyi useita sivuhaaroja, lähinnä Jutilan poliittisten harrastusten tuloksena. Hän oli maalaisliiton kansanedustaja v. 1945, valtioneuvoston jäsenenä 5 kertaa, ensiksi salkuttomana ja myöhemmin apulaismaatalousministerinä $1927-28$, maatalousministerinä $1932-36,1945$ ja $1953-54$ sekä kansanhuoltoministerinä 1944-45. Maalaisliittolaisen, Helsingissä ilmestyneen Suomenmaa-lehden päätoimittajana Jutila toimi vv. 1930-31. Poliittiseen linjaan voidaan myös lukea Suomen lähettilään tehtävät Washingtonissa vv. 19451951, Havannassa 1948-51 ja Mexicossa 1950-51.

$\left.{ }^{1}\right)$ Suomen Maataloustieteellisen Seuran kokouksessa pidetty muistopuhe.

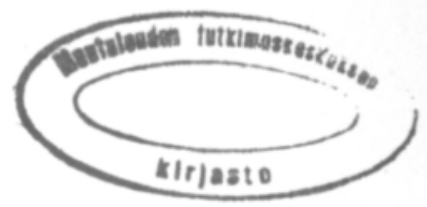


Jutila osallistui tehokkaasti lukuisien maataloudellisten ja osuustoiminnallisten järjestöjen ja laitosten toimintaan erilaisissa tehtävissä, toimi samoin puheenjohtajana tai jäsenenä monissa valtion komiteoissa sekä teollisuuslaitosten, pankkien ja vakuutuslaitosten hallintoneuvostoissa ja johtokunnissa. Hän oli kaksi kertaa edustajana kirkolliskokouksessa. Vuonna 1939 hän toimi New Yorkissa maailmannäyttelyn Suomen osaston pääkomissaarina.

Jutila otti osaa moniin ulkomaisiin maatalouskongresseihin. Hän oli Suomen valtuuskunnan puheenjohtajana FAO:n kongressissa Roomassa 1953 ja kongressin varapuheenjohtaja sekä ulkoministeriön määräämänä valtion edustajana Delawaren asutuksen 300-vuotisjuhlassa $1937-38$.

Laajan ja monisäikeisen virkatyön ja yhteiskunnallisen toiminnan ohella Jutila ehti suorittaa myös runsaasti tieteellistä työtä maatalouspolitiikan alalla. Erikoisesti huomattakoon hänen laajat tutkimuksensa Perä-Pohjolan ja Lapin maa- ja metsätalousoloista ja asutuspolitiikasta. Näiden tutkimusten pohjalla julkaistun 4-osaisen "Tutkimuksia Perä-Pohjolan ja Lapin asutus- ja talousoloista». Osa II "Varsinaisen itsehoidetun maatalouden pääomasuhteista» oli väitöskirja. Muita tärkeimpiä Jutilan tieteellisen tutkimustyön kohteita ovat olleet vuokranmaksun synty, historiallinen kehitys ja tarkoituksenmukainen määrääminen, maatalouden osuus Suomen kansallisvarallisuudesta, maatalouden tutkimus-, opetus- ja neuvontatyö Suomessa, tullien vaikutus Suomen maatalouteen ja maatalousväestön kulutustalouteen, Suomen pienviljelyn tila ja sen tarpeet, Suomen elintarviketalous ennen ensimmäistä maailmansotaa, Suomen maatalouspolitiikka 20:nnella vuosisalla, Suomen maatalous itsenäisyyden aikana, Suomen maatalous ja yleismaailmallinen maatalouspula, maatalouden tuotantosuunta ja valuuttatilanne, maanviljelys- ja maamiesseurat ennen itsenäisyyden aikaa, maatalouden edistämisjärjestöt jtsenäisyyden aikana ja maatalouskerhotoiminta. Englanninkielellä Jutila julkaisi tutkimuksen maatalouspulasta Suomessa vv. 1928-35, sen torjumisessa käytetyistä menettelytavoista sekä saavutetuista tuloksista ja katsauksen Suomen elintarvikeomavaraisuuteen toisen maailmansodan puhjetessa.

Minulla oli ilo kuulua Jutilan oppilaisiin, olla hänen työtoverinaan useissa komiteoissa ja toimia hänen alaisenaan kansanhuoltoministeriössä sekä Suomen lähetystössä Washingtonissa.

Jutila oli innoittava opettaja. Hänen eloisa luonteensa ja laajaan lukeneisuuteen perustuva tietorikkautensa tulivat täysin oikeuksiinsa luennoimisessa, joka piti kuulijat kaiken aikaa virkeinä ja vastaanottavina. Hän kuului ensimmäisiin Helsingin yliopiston opettajiin, jotka olivat tutustuneet Yhdysvalloissa noudatettuihin uudenaikaisiin opetusmenetelmiin ja me hänen oppilaansa saimme tästä hyödyn. Parastaan antoi Jutila kuitenkin henkilökohtaisessa oppilaitteensa opastuksessa, johon hän aina, monista töistään ja kiireistään huolimatta, koetti varata aikaa ja harrastusta. Opiskelija tunsi hänet enemmänkin vanhemmaksi ja tietorikkaammaksi toveriksi, jonka kanssa voi vapaasti vaihtaa mielipiteitä ja olla vaikkapa jyrkästi eri mieltä, kuin arvovaltaiseksi professoriksi, jonka käsitykset tuli nöyrästi omaksua.

Jutila piti hyvää huolta tieteellisestä jälkikasvusta omalla alallaan, auttoi oppilaitaan tieteellisessä työssä ja koetti järjestää heille myös ulkomaisia opiskelu- 
ja tutkimusstipendejä, jollaisen hänen ansiostaan minäkin sain, vaikka kohtalo sitten ohjasikin minut muuhun kuin tieteelliseen elämäntehtävään.

Komiteatyössä Jutila oli erittäin aktiivinen ja sovittelevan luonteenlaatunsa puolesta myönteinen voima niin hyvin puheenjohtajana kuin jäsenenäkin. Taloudellisessa puolustusneuvostossa, jonka jäsen ja maatalousjaoston puheenjohtaja Jutila oli, sain kymmenen vuoden ajan neuvoston virkamiehenä ja maatalousjaoston sihteerinä nauttia hänen asiantuntevasta avustaan.

Suomen lähetystön päällikkönä Washingtonissa Jutila toimi 5 vuoden ajan heti sodan jälkeen. Tehtävä oli vaativa. Katkenneet suhteet oli uudelleen rakennettava ja sodan köyhdyttämälle sekä sotakorvauksia suorittavalle kotimaalle oli koetettava hankkia sekä rahalainoja että tavaraa. Tämä kaikki oli saatava aikaan kilpaillen kymmenien muiden, samoja asioita Washingtonissa tavoittelevien lähetystöjen kanssa, joista useimmat vielä — joko sodanaikaisina liittolaisina tai puolueettomina — olivat edullisemmissa asemissa kuin sodan jatkovaiheessa vihollismaihin kuulunut Suomi. Vanhaa 'goodwill'iä Suomella oli velanmaksun ja talvisodan ansiosta runsaasti, mutta ensimmäisinä vuosina Washingtonin lähetystömme uudelleen avaamisen jälkeen saattoi esim. laina- ja tavarapyyntöjä käsittelevissä virkamiehissä todeta eräänlaista pidättyväisyyttä, joka sitten ajan oloon hälveni. Jutila onnistui lähinnä myönteisten henkilökohtaisten ominaisuuksiensa ansiosta herättämään jälleen eloon vanhan "goodwill»in. Yhdysvalloissa opiskelleena ja tutkimustyötä tehneenä hän oli hyvin perillä amerikkalaisten mentaliteetista ja osasi sopeuttaa toimintansa sen mukaan.

Jutila oli erittäin pidetty esimiehenä. Hän oli vaatimaton, kaikille erotuksetta ystävällinen ja säilytti vaikeuksissakin optimistisen uskon, että kaikki lopulta kääntyy parhain päin. Yleensä hänen alaisensa palvelivat häntä innokkaasti omasta halustaan ja näin saavutettiin hyviä tuloksia työssä.

Jutila oli oivallinen keskustelija ja pidetty seuramies. Hänellä oli loppumaton valikoima sananparsia ja kansan sanontoja, joilla hän elävöitti puhettaan. Muistan erään keskustelun korkean amerikkalaisen virkamiehen kanssa. Tämä halusi Suomen lähettilältä kuulla, millaisiksi olivat suhteemme suureen itäiseen naapuriimme muodostuneet. Jutila totesi suhteiden kehittyvän myönteiseen suuntaan, mutta tietenkin vaativan käydyn sodan jälkeen hyvin varovaista käsittelyä. "Me suomalaiset" sanoi Jutila, "koetamme nykytilanteessa olla aivan yhtä hiljaa kuin hiiri jauhovakkasessa». Kun joskus olin huolestunut siitä, että minulla ei ollut riittävästi aineistoa taloudellisen raportin laatimiseksi ulkoministeriölle, rohkaisi Jutila, että "tehdään sitten vain niin suuri kuin aineesta tulee».

Professori Jutilassa meni manalle innoittava opettaja, vireä tiedemies, lukuisat ja vaativat yhteiskunnalliset ja valtiolliset tehtävänsä hyvin suorittanut käytännön mies ja sydämellinen, hyvä ihminen.

Artturi Lehtinen

Professori K. T. J u t il a n julkaisuja

1920-23 Tutkimuksia Perä-Pohjolan ja Lapin talous- ja asutusoloista, I-IV. Osa II, väitöskirja: Varsinaisen itsehoidetun maatalouden pääomasuhteita. 
1923 Tutkimuksia vuokranmaksun synnystä, historiallisesta kehityksestä ja tarkoituksenmukaisesta määräämisestä. I. Tutkimusmenetelmistä, käsitteistä ja yleisistä periaatteista .

1926 Maatalouden osuus Suomen kansanvarallisuudesta. Yhteiskunnallinen Aikakauskirja.

$\rightarrow$ - Nykyisestä tutkimus-, opetus- ja neuvontatyöstä maatalouden taloustieteen alalla Suomessa.

$\rightarrow-$ Tullien vaikutuksesta maanviljelijäin ruokataloudessa.

$\rightarrow-$ Tullien vaikutuksesta Suomen maatalouteen ja maatalousväestön kulutustalouteen.

$\rightarrow$ - Pienviljelyksemme nykyinen tila ja tarpeet.

1932 Elintarvikkeiden saanti ja käyttö vuosittain keskim. vv. 1911 - 13.

1936 Suomen maatalouspolitiikka 20:nnella vuosisadalla. Maatalouspula Suomessa vuosina $1928-35$. Yhdessä J. Konttisen kanssa.

1937 The agricultural depression in Finland during the years 1928-35. The measures employed for it and the results obtained.

1938 Suomen maatalous itsenäisyyden aikana.

$\rightarrow$ - Suomen maatalous ja yleismaailmallinen maatalouspula vv. $1929-36$.

1940 Finlands selfsufficiency in foodstuffs.

1956 Maatalouden tuotantosuunta ja valuuttatilanne.

1962 Maanviljelys- ja maamiesseurat ennen itsenäisyyden aikaa.

$\rightarrow-$ Maatalouden edistämisjärjestö itsenäisyyden aikana.

$\rightarrow-$ Maatalouskerhotoiminta. 